World Lumen Congress 2021 | May 26-30, 2021 |

Iasi, Romania

\title{
Multicultural Education: Ukrainian Challenges
}

\section{Olha SVYRYDIUK, Svitlana SHUMAIEVA, Vitalii SVYRYDIUK}

https://doi.org/10.18662/wlc2021/62

How to cite: Svyrydiuk, O., Shumaieva, S., \& Svyrydiuk, V. (2021). Multicultural Education: Ukrainian Challenges. In A. Sandu (vol. ed.), Lumen Proceedings: Vol. 17 World Lumen Congress 2021 (pp. 630-640). Iasi, Romania: LUMEN Publishing House. https://doi.org/10.18662/wlc2021/62 


\title{
Multicultural Education: Ukrainian Challenges
}

\author{
Olha SVYRYDIUK ${ }^{1}$, Svitlana SHUMAIEVA ${ }^{2}$, Vitalii SVYRYDIUK ${ }^{3}$
}

\begin{abstract}
Ukraine is a multinational and multicultural country. Though Ukerainian scientists have studied the issue of multicultural education from different aspects, nevertheless, there is no special or ideal model of multicultural education. That is why we decided to monitor the students' multicultural education state at secondary schools of Ukraine. In order to identify the state of multicultural education in Ukrainian schools we conducted an empirical study in schools of Cherkasy region among primary, secondary and senior level students. The main method was determined as questionnaire, which is provided for clarification of issues of national-patriotic and multicultural orientation. Accordingly, questionnaires that combined quantitative and qualitative data collection were offered to the 4th, 6th and 11th grade students in some schools in Uman and Uman district, covering 296 respondents. Thus, the monitoring of the state of multicultural education in Ukrainian school education has shown that the problem of multicultural upbringing of children and young people is addressed at the government level, relevant research is conducted, some aspects of multiculturalism are observed in educational programs of some subjects, but the level of multicultural education of students should be bigher.
\end{abstract}

Keywords: Multiculturalism, multicultural education, identity, diversity, cultures.

\section{Introduction}

The integration processes taking place in Ukraine, Eurocentricity, encourage current generation to be capable to coexist with other people and social groups. Therefore, along with patriotic and civic education, an important role belongs to the students' multicultural education in general educational institutions as the most wide-scale socio-educational establishments of the present. Ukraine belongs to states with a multicultural environment that has been formed on its territory for centuries. In addition, it unites people of different nationalities with all forms of interaction and mutual influence. Ukraine is a multinational state that has more than a hundred nationalities.

According to the last census of the population (2001), the national (ethnic) minorities in Ukraine were 14 million people, or $27.3 \%$ of all residents. Representatives

\footnotetext{
${ }^{1} \mathrm{PhD}$, Associate Professor, Pavlo Tychyna Uman State Pedagogical University, Uman, Ukraine. o.svyrydiuk@udpu.edu.ua

2 PhD, Associate Professor, Pavlo Tychyna Uman State Pedagogical University, Uman, Ukraine. s.shumaeva@udpu.edu.ua

${ }^{3}$ PhD, Pavlo Tychyna Uman State Pedagogical University, Uman, Ukraine. vetal-79@i.ua
} 
from more than 100 nations live here. The most numerous of them are Russians, Jews, Polish, Belarusians, Moldovans, Tatars, Gypsies, Bulgarians, Hungarians, Romanians, Greeks, Armenians, etc. (State Statistics Committee of Ukraine, 2001).

As of today, Ukraine has neither created an ideal model for organizing multicultural education, nor determined the essence of its important component multicultural education yet. In the broadest sense, multiculturalism is the formation of global thinking, the perception of the world in its various manifestations, the forms of existence of languages, cultures, and attitudes that implies the existence of a humanistic world outlook, such qualities as tolerance, the ability to conduct dialogue on equal rights, mutual respect. These ideas are reflected in a variety of humanist-oriented trends aimed at enforcing human rights for the sake of peace and development, fostering the provision of global education, and the implementation of multicultural education (Agadullin, 2004, p. 18).

\section{Review of literature}

American scientists Banks (1994), Gay (2000), Gollnik and Chinn (1990), Gorski (2000), Kim (1987), Nieto (2010) and Sleeter and Grant (1988) offer an indepth analysis of theoretical ideas that are reflected in different approaches to multicultural education.

Gollnik and Chinn (1990) and Kim (1987), presented the following definition: "Multicultural education is an educational strategy in which the cultural mentality of students is seen as positive and central to the organization of the learning process."

Multicultural education should help young people "understand thoughts, behaviors, and facts from the point of view of their own ethnic roots and from the point of view of other nationalities. In such educational process, students will realize the essence of racism (ethnocentrism) and understand the interdependent organization of human society, as well as the contribution that different ethnic groups make to the development of the world ( Kim, 1987).

«Multicultural education is a progressive approach to the transformation of education that holistically criticizes and responds to discriminatory laws and practices in the field of education. It is based on the ideas of social justice, equality in education, commitment to methods that allow students to realize their potential, to be active in local, national and global communities» (Gorski, 2000).

According to the famous American researcher Sonya Nieto (2010), multicultural education and training is anti-racist, important for all students, teaching about social justice and critical pedagogy. Recognition of differences and acceptance of cultural realities are fundamental to multicultural education. Teachers are guided by the principles of freedom, acting in the educational process as supporters of social justice and carrying out critical learning in a multicultural environment (Nieto, 2010).

Professor Banks is widely considered as the "father of multicultural education" in the United States and is known throughout the world as one of the 
field's most important founders, theorists, and researchers. Due to his theory "Multicultural education is an idea or a concept, an educational reform movement, and a process (Banks, 2013). Multicultural education incorporates the idea that all students - regardless to their gender, sexual orientation, social class, and ethnic, racial, or cultural characteristics - should have an equal opportunity to learn at school. Another important idea in multicultural education is that some students, because of these characteristics, have a better chance to learn at schools as they are currently structured than do students who belong to other groups or who have different cultural characteristics. Theory and research in multicultural education indicate that the total school must be reformed in order to implement multicultural education comprehensively and effectively (Banks, 2013).

Most multicultural education theorists agree that the major goal of multicultural education is to restructure schools, colleges, and universities so that all students will acquire the knowledge, attitudes, and skills needed to function in an ethnically and racially diverse nation and world. The definitions of multicultural education intertwine its diverse models adopted in different countries, as well as reflect its constituent components. (Gay, 2012; Nieto, 2012).

The Ukrainian researcher Loshchenova (2004), analyzing the well-known today is concept of multicultural education, emphasizes that its main task is the development cognitive and non-verbal skills that enable them to interact with other cultures and their carriers. By linking multicultural education with higher levels of education and achievement of success in a multicultural environment, the researcher singles out four of its functions: the formation of the understanding of diversity of cultures and their interrelationship among those who study; the awareness of the importance of cultural diversity for the individual's self-realization; the formation of the positive attitude to cultural differences; the development of skills of interaction of carriers of different cultures on the basis of tolerance and mutual understanding.

After deep analyzing the literature and opinions of different scientists we sum up with such statement that multicultural education in school education means an interdisciplinary process that ensures the full development of students' potential and critical abilities regardless of differences based on racial, ethnic, gender and class stratification of society and provides deep awareness of skills and abilities that are necessary for life in a pluralistic society.

\section{Design and methods}

The aim of this article is to monitor the students' multicultural education state at secondary schools of Ukraine.

\subsection{Methodology}

Our research was conducted on analyzing state documents and school curricular and doing an empirical study in schools of Cherkasy region among primary, secondary and senior level students.

The analysis of students' modern multicultural education in secondary schools 
of Ukraine has shown that at the state level such documents as Framework Convention for the Protection of National Minorities, 1997; the Law "On Education", 2017; the Concept of Civic Education and Education in Ukraine,2018; the National Strategy for the Development of Education in Ukraine until 2021, 2013; the Concept of National-Patriotic Education of Children and Youth, 2015 and others provide essential support for the development of multicultural education.

The analysis of school curricula has shown that aspects of multicultural education are considered in the content of certain subjects (Foreign literature, Foreign language, Physics, History and Geography) through a sociocultural content line that is a means of mastering national, universal cultural and spiritual values, rules governing relations between generations, genders, and nations, contribute to the aesthetic and moral, and ethical development of the individual, the smooth entry into society. Such subjects as Ukrainian Language and Literature, Art, Mathematics primarily focus on patriotic and national education. However, programs for 5-9 forms on such subjects as: Computer Science, Biology, Chemistry, Basic Health Education, Labor Training, Physical Training fail to provide the multicultural orientation of their content.

The study of curricula in schools with a high percentage of national minorities has shown that multicultural education occupies the important place, and is made through a system of personal relationships with a new culture in the process of mastering it.

As a result, students have acquired such qualities as: positive attitude towards the languages of minorities as a means of communication; respect for the people; tolerant attitude to the culture, customs and way of life; culture of communication, adopted in the modern civilized world; emotional value, relation to the world around; understanding the importance of mastering minority languages and the need to use them as means of communication.

In order to identify the state of multicultural education in school education of Ukraine, we conducted an empirical study in schools of Cherkasy region among primary, secondary and senior level students. The main method was determined as questionnaire, which provided for clarification of issues of national-patriotic and multicultural orientation. Accordingly, questionnaires were offered to the 4th, 6th and 11th grade students in some schools in Uman and Uman district, covering 296 respondents.

We used two questionnaires that combined quantitative and qualitative data collection, namely: the author's questionnaire - in the 4th and 6th grades, and a scale questionnaire by a researcher Romanova O. L. (1994) in the 11th grade for the study of the ethnic identity of children and adolescents.

\section{Results and discussion}

The first questionnaire has enabled to assess the level of awareness of national identity and other peoples, as well as their views on other peoples. The questions of national identity include: "What does Ukraine mean for you?" "How do you 
understand the term "Ukrainian?" "What symbols of Ukraine do you know?"

The awareness of other peoples should have checked the following questions: What other countries do you know besides Ukraine? What countries are on the border of Ukraine? What other peoples live in Ukraine, in addition to Ukrainian?

The following issues were to find out the respondents' opinion: How did you find out about other peoples? On the other hand, what would you like to know about other peoples? Have you ever met the representatives of other peoples, and what exactly did you impress when you met them? How can different peoples live in one locality?

The overwhelming majority of respondents have answered the question "What does Ukraine mean for you?" as follows: the Motherland, 10\% of them have added another concept to the native land of an independent, strong spirit nation.

Respondents understand the concept "Ukrainians" as "people who live in Ukraine and are patriots", "citizens of Ukraine", "people who love Ukraine", "people who speak Ukrainian".

The great majority, amounting to $60 \%$, know the national symbols, another part of respondents $(40 \%)$ adds popular symbols to the national ones, and only a small percentage of respondents names the public symbols of Ukraine. Thus, the answers to the first pool of questions show that students of grade 4 have formed knowledge about the basic concepts "Ukraine", "Ukrainian", and the national and public symbols of Ukraine that testifies a high level of participants' national education.

One hundred percent of respondents know that Ukraine is not the only country in the world.

Among the countries the respondents named, the most frequently mentioned were USA, Canada, France, Brazil, Italy, Poland, Belarus, Turkey, Germany, China, Romania. Germany, Serbia, Austria, Sweden, Switzerland, Moldova, Japan, England, Spain, India, Finland, Georgia, Australia, Israel, Portugal, Bulgaria are the countries least mentioned in respondents' responses.

The following diagram shows the answers to the question "What other peoples, in addition to Ukrainians, live in Ukraine?" The overwhelming majority of answers (90\%) included Poles, Russians, Belarusians, only two groups of respondents added Moldovans and Crimean Tatars, Hungarians, Turkmens, Hasids; the one group of respondents mentioned Romanians, Slovaks, Gypsies, Armenians, Georgians, Jews. 


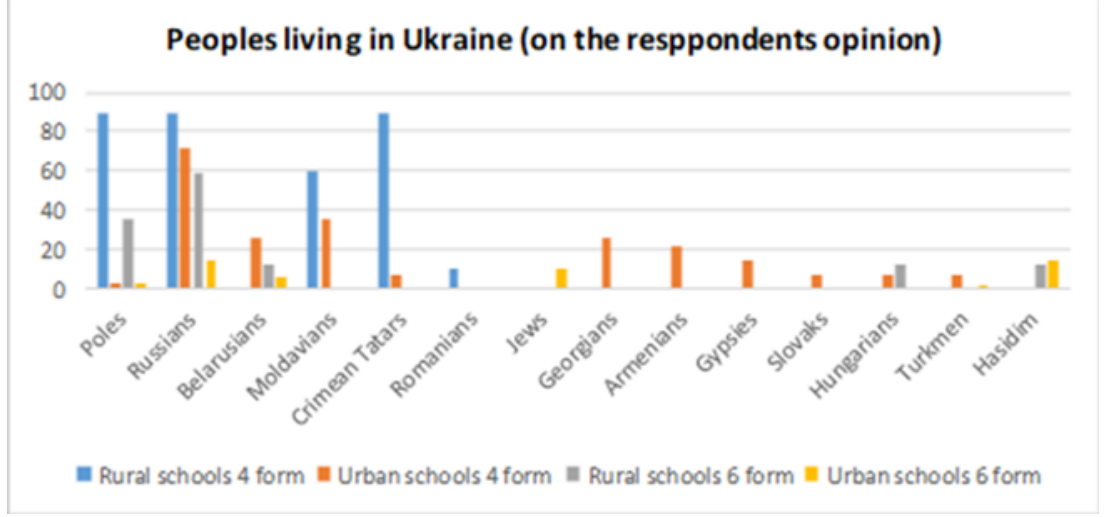

Fig. 1. Peoples living in Ukraine (on the respondents' opinion)

The following diagram shows the sources, from which respondents get knowledge about other peoples. Thus, $70 \%$ of respondents of the 4th grade of rural schools named "television", 50\% - "family" 20\% - "Internet" and 5\% - "school", and $64.6 \%$ of respondents of the 6th grade named "school", $41 \%$ - Internet, television and family shared the third position, amounting to $29.5 \%$. For the 4 th grade of urban schools, the main sources are school and family (40.9\%), the television (13.65\%) and the Internet are in the last place (4.55\%). The diagram shows that for the 6th grade of urban schools, all sources occupy roughly equal positions.

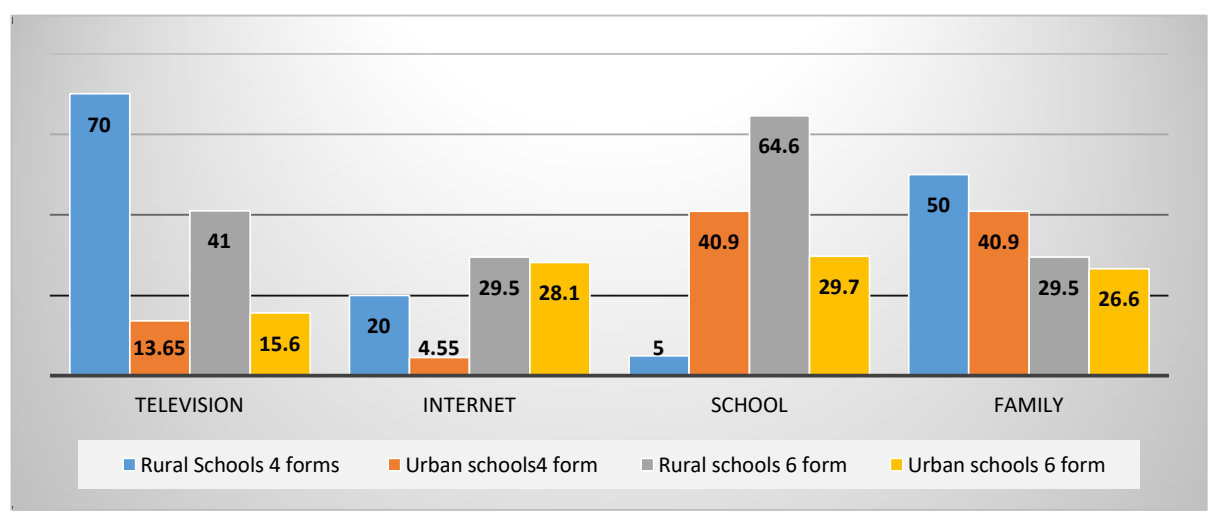

Fig. 2. Sources from which students get information about other peoples

Ninety percent of respondents answered "Yes" and ten percent answered "No" to the question "Have you ever met with representatives of other peoples?" Regarding their impressions while meeting the people of other nationalities, the overwhelming majority were impressed by the appearance, color of the skin and obscure language of foreigners. Some noted the difference in the cuisine, customs and traditions. To the question "Would you like to learn more about other cultures?" the overwhelming majority have answered "Yes" that indicates the desire to learn more about other peoples, namely, language, skin color, communication style, national clothes, everyday life, habits, holidays, traditions, dishes, art, architecture, memorials, history, folk art, poetry, symbols, folk features, what the nations are, whether they have 
schools, what kind of people they are, what rules they have, whether such laws and ordinances are those which are applied in our country or not.

Answering the question "In your opinion, how different peoples can successfully live in one locality?", respondents indicated the following: "tourist way", "peace", "peace, mutual understanding", "to accept people with whom they are", "to be friendly", "not to violate the laws", "not to show racism", "to work together", "to respect each other", "to preserve customs", "friendship when they understand each other", "have equal rights, duties", "obey the laws", "adhere to customs", "help each other", "do not talk down on other peoples", "friendship", "family", respect", "respect each other's privacy", "learn Ukrainian language", "live in different districts", "I do not know", "bad", "very good".

Thus, the results of the first test indicate the formed patriotic feelings, the awareness of their own identity, but it is noticeable that the awareness of other countries, peoples is at the secondary level, and even the respondents themselves indicate that they need more information on the peoples living on the territory of Ukraine. The rating of sources has indicated the low activity of schools on the dissemination of information about other peoples.

The second test for high school students contains the following pools of questions: belongingness to their ethnic group (question No. 1. "I am interested in the history, culture of my nation"; No. 6. "If I hear anything offensive about people of my nation, it wounds my self-esteem"; No. 10. "I have a deep sense of personal pride, when I hear anything about the outstanding achievements of my nation"; No.14. "If I hear accusations against my people, then, as a rule, I do not attribute it to myself"; No. 20. "If I had the opportunity to choose a nationality, I would prefer the one I have now"); significance of nationality (question No. 2. "I believe that in any interethnic controversy, a person must defend the interests of his or her people"; No. 4. "I think that national pride is a feeling that needs to be raised from childhood"; No. 5. "I think that when communicating with people, you need to focus on their personal qualities but not on their nationality"; No.7. "National affiliation is something that will always disunite people"; No. 9. "In friendship it is necessary to consider the nationality of the partner"; No. 12. "I think that it is natural to develop and preserve only one's own national culture"; No. 13. "I support mixed relationships as they connect different peoples among themselves"); the interactions of the ethnic majority and minorities (question No. 8. "I believe that representatives of every nationality should live on the land of their ancestors"; No.11. "I believe that people have the right to live in any territory regardless of their nationality"; No.16. "Representatives of the native majority of the population should not have any advantages over other peoples living on the given territory"; No.17. "I believe that representatives of native people have the right to decide whether people of other nationalities may live in their state or not"; "I think that the government of a multinational state should include representatives of all nationalities living on this territory"; No.19. "I think that representatives of native nationality should have certain advantages, since they live on their territory"); the use of one or another language (question No. 3. "Representatives of the same 
nationality should communicate in their own language"; No.15. "I believe that workflow management and teaching in schools in a multinational state should be arranged in the language of the indigenous majority").

The answers to questions aimed at feeling of belonging to their ethnic group have shown a high level of formation of feelings of a national character.

The answers to questions that focus on the interactions of the ethnic majority and minorities and the use of one or another language indicate an insufficient level of multicultural feelings, such as to the question "Representatives of the native majority of the population should not have any advantages over other peoples living on the given territory" the answers were as follows: "absolutely agree" - 29.5\%, "more likely agree than disagree" - 5.9\%, "difficult to say" $35.2 \%$, "rather disagree than agree" - 17.65\%, "strongly disagree" - 11.75\%.

The monitoring of the state of multicultural education in Ukrainian schools has shown an adequate level of students' patriotic feelings and self-knowledge, and it has been noted that the awareness of other countries and peoples is at the secondary level. The respondents themselves have indicated that they need more information on the peoples who live on the Ukrainian territory. The answers to the questions aimed at identifying the level of the formation of belonging to one or another ethnic group have shown a high level of the formation of feelings of a national character. However, the answers to the questions that are aimed at identifying the interactions of the ethnic majorities and minorities and the use of one or another language have indicated that the multicultural feelings are not well developed.

\section{Conclusions}

The analysis of modern multicultural education of students in secondary schools of Ukraine is carried out. It was revealed that at the state level a number of documents - the Declaration of State Sovereignty of Ukraine, the Declaration of the Rights of Nationalities of Ukraine, the Constitution of Ukraine, the Law of Ukraine "On National Minorities in Ukraine", the Law of Ukraine "On Child Protection", National Strategy for the Development of Education in Ukraine until 2021 "," The Concept of National-Patriotic Education of Children and Youth ", etc. - provide thorough support for the development of multicultural education.

In particular, these documents pay considerable attention to the rights of national minorities and profess the principles of inadmissibility of their discrimination, manifestations of racism, xenophobia, anti-Semitism; recognition of multiethnicity, multilingualism, multiculturalism as an important achievement of humanity, a sign of the wealth of society; tolerance.

It was found that among the principles of patriotic education, reflecting its specifics in domestic education, the following deserves attention: the principle of multiculturalism, which provides for the integration of Ukrainian culture into the European and world space, creating the necessary prerequisites for this: tolerant attitude to different ideas, values, culture, art, beliefs of other peoples; the ability to 
differentiate common and different in different cultures, (to identify similarity and diversity of different countries) the ability to perceive Ukrainian culture as an integral part of universal culture; the principle of intergenerational continuity, which preserves for posterity samples of Ukrainian culture and the culture of the peoples living in Ukraine.

Analysis of school curricula showed that aspects of multicultural education are considered in the content of individual subjects (foreign literature, foreign language, physics, history and geography) through the socio-cultural content line, which is a means of mastering national, universal cultural and spiritual values, norms governing relations between generations, genders, nations, contribute to the aesthetic and moral and ethical development of the individual, his organic entry into society. Such subjects as Ukrainian language and literature, art, mathematics are mainly aimed at patriotic and national education. However, the programs for grades 5-9 in such subjects as: computer science, biology, chemistry, basics of health, labor training, physical culture (training, education) do not trace the multicultural orientation of their content.

A study of curricula for teaching subjects in schools with a significant percentage of students of national minorities showed that multicultural education in them occupies an important place and is carried out through a system of personal relationships with the new culture in the process of mastering it. This is facilitated by the education of students in the following qualities: a positive attitude towards minority languages as a means of communication, respect for the people who speak this language, a tolerant attitude towards their culture, customs and way of life; the culture of communication adopted in the modern civilized world; emotional and value attitude to everything around; understanding the importance of mastering minority languages and the need to use them as a means of communication.

The monitoring of the state of multicultural education in Ukrainian schools showed the appropriate level of patriotic feelings and knowledge of one's own identity, but it was noted that knowledge about other countries and peoples is at an average level and even the respondents themselves say they need more information about the peoples living there, on the territory of Ukraine. Answers to questions aimed at identifying the level of formation of belonging to a particular ethnic group showed a high level of formation of feelings of national character. However, the answers to the questions, which are aimed at revealing the relationship between the ethnic majority and minorities and the use of one or another language, indicate an insufficient level of formation of multicultural feelings.

Based on the analysis of theoretical principles and study of practical experience of multicultural education of students in the Canadian and native school education system, recommendations for the use of Canadian experience in Ukrainian educational institutions are developed: to monitor and evaluate teaching materials, providing recommendations to avoid injustices and stereotypes; encourage and support the development of criteria to ensure equal educational opportunities, regardless of race, color, sex, language, cultural heritage, religion, ethnicity, physical ability or intellectual potential; organize consultations, formal and 
informal, with representatives of the nation national minorities, to develop partnerships with ethnocultural communities. In order to implement these recommendations, it is necessary to develop topics for multicultural education electives for secondary schools, multicultural education programs for out-of-school children's institutions and summer health camps, the national situation in the field of multicultural education and development strategies; to modernize curricula and textbooks in accordance with the goals of multicultural education.

For the purpose of multicultural training of pedagogical workers it is offered to enter a special course on multicultural education in the curricula; to ensure the continuous development of professional on-the-job programs for the administration, teachers and support staff; organize and conduct seminars, pedagogical workshops and master classes on multicultural education.

The importance of involving students in active participation in international projects, which will help to establish communicative ties between students from different cultures, based on the ideas of mutual understanding, cooperation, respect for human rights and fundamental freedoms has been proved. Effective implementation of multicultural education in modern Ukrainian school education is possible provided the creation of a multicultural environment in schools and classrooms through the introduction of school electives to study the cultural heritage of ethnic minorities, purposeful addition of extracurricular educational work with multicultural students, taking into account regional aspects.

\section{References}

Agadullin, R. R. (2004). Multicultural education: methodological and theoretical aspect. Pedagogy and Psychology, 3, 18-29. https://public.scnchub.com/perm/index.php/perm/article/download/61/57

Banks J. (1999). An introduction to multicultural education. Allyn and Bacon.

Banks, J. A. (2013). Multicultural education: Characteristics and goals. In J. A. Banks \& C.

A. M. Banks (Eds.), Multicultural education: Issues and perspectives (8th ed., pp. 3-23). Wiley.

Gay, G. (2012). Multicultural education: Purposes and goals. In J. A. Banks (Ed.), Encyclopedia of diversity in education (Vol. 3, pp. 1547-1552). Sage Publications.

Gollnik, D. M., \& Chinn, P. C. (1990). Multicultural education in a pluralistic society. Merrill.

Gorski, P. (2000). Multicultural education and the internet: Intersections and integrations. McGrawHill.

Kontseptsia hromadianskoi osvity ta osvity v Ukraini. (2018). (Cabinet of Ministers of Ukraine). [Concept of Civic Education and Education in Ukraine 2018 (Cabinet of Ministers of Ukraine)]. Vidomosti Verkhovnoi Rady Ukrainy [Order of Cabinet of Ministers of Ukraine].

Kontseptsiia natsionalno patriotychnogo vykhovannia ditei ta molodi. (2015). (Ministry of Education and Science Of Ukraine). [Concept of National-Patriotic Education of Children and Youth, and others 2015 (Ministry of Education and Science of Ukraine)]. Vidomosti Verkhovnoi Rady Ukrainy [Order Ministry of Education and Science of Ukraine]. 
Loschenova, I. F. (2004). Multicultural education of future teachers in the process of learning foreign languages [Unpublished doctoral dissertation, Institute of Problems of Education of the Academy of Pedagogical Sciences of Ukraine at Kyiv].

Natsionalna strategia rozvytku osvity v Ukraini do 2021. (2013). (President of Ukraine). [National Strategy for the Development of Education in Ukraine until 20212013 (President of Ukraine)]. Vidomosti Verkhovnoi Rady Ukrainy [Decree President of Ukraine].

Nieto, S. (2012). United States, multicultural education in. In J. A. Banks (Ed.), Encyclopedia of diversity in education (Vol. 4, pp. 2248-2253). Sage Publications.

On Ratification of the Council of Europe Framework Convention for the Protection of National Minorities. Law of Ukraine on December 9, 1997. 703/97-BP. https://zakon.rada.gov.ua/go/703/97-0 $\%$ D0\%B2\%D1\%80

Romanova, O. L. (1994). Development of ethnic identity at children and teenagers. [Unpublished doctoral dissertation, Moscow Humanitarian University named after M. V. Lomonosov at Moscow].

State Statistics Committee of Ukraine. (2001). About number and composition population of UKRAINE by data All-Ukrainian population census'2001 data. Urkcensus. http://2001.ukrcensus.gov.ua/eng/results/general/nationality/

Zakon pro osvitu. (2017). (Verkhovna Rada Ukrayiny). [Law On Education 2017 (Verkhovna Rada of Ukraine)]. Vidomosti Verkhovnoi Rady Ukrainy [Statements of Verkhovna Rada of Ukraine], 38-39, 180. 